\title{
Asset Pricing and Evidence of Price Discovery in Sustainable Equity Portfolios
}

\section{Abdul Qadeer* and Ashfaq Ahmad**}

\begin{abstract}
Using the Fama-French three factor method, the size sorted liquidity-based three factor method, and the Fama-French five factor model, this study explores the dynamics of price discovery and asset pricing in sustainable equity portfolios. Based on the findings of the study, we propose the liquidity based three factor model as a significant explanatory model for the pricing of sustainable equity portfolios in Pakistan. However, all the five factors i.e., market premium, size premium, value premium, operating profitability, and the investment factors from the FamaFrench five factor regression for small conservative and small stocks with high Book-to-Market were observed to be significant. Furthermore, we found evidence of the price discovery variable in some portfolio classes that were constructed from the asset pricing models. The findings of this study suggest that in Pakistan, liquidity is a critical pricing factor, and should not be overlooked while making investment decisions. Furthermore, portfolios where price discovery were found may be useful for further portfolio optimization and profit maximization.
\end{abstract}

Key words: Asset pricing, price discovery, Fama-French.

JEL classification: G10, G11, G12.

\section{Introduction}

Asset pricing has been a widely researched topic in the discipline of finance (Lettau \& Pelger, 2020). Moreover, it is an important area of observation, both in academia (Hammami \& Lindahl, 2013) and practice, as it provides the basic framework in understanding the dynamics of equity return (Sha \& Gao, 2019). The field of academics has put a considerable effort into this discipline, so as to better understand implications that exist for asset pricing for equity investment. However, as discussed by O'Hara (2003), asset pricing has a meaningful theoretical link

\footnotetext{
* Lecturer, Superior University, Lahore; Doctoral Student, Hailey College of Commerce, University of the Punjab Lahore, Pakistan; Doctoral Research Fellow, Solvay Business School, Vrije Universiteit Brussels (VUB), Belgium.

${ }^{* *}$ Associate Professor, Hailey College of Commerce, University of the Punjab, Lahore, Pakistan.
} 
with price discovery, which is a vital aspect of market microstructure, and an important function of the market along with liquidity. The definition of price discovery in the literature of market microstructure focuses on the adjustment of new information into asset prices (O'Hara, 2003; Narayan, Phan, Thuraisamy and Westerlund, 2016). The basic purpose of the presidential address was to highlight the knowledge void in the field of price discovery and asset pricing. The idea was that price discovery is theoretically linked with asset price predictability. This was in the sense that when there is asymmetric information, uninformed investors face a factor of risk differential. Therefore, price discovery affects the investor's risk, and then price discovery should affect the asset returns.

Gavious and Kedar-Levy (2013) also mentioned that the theoretical exploration of an asset price with price discovery is rare. In addition to this, following the gap in the literature, Narayan et al. (2016) also explored the area of asset pricing, and pointed out that the relation of price discovery with asset pricing was a phenomenon that was poorly known. In addition to price discovery, following the recent work by Miralles-Quirós et al. (2020), this study focuses on the assets related to Sustainable Development Goals (SDGs), which comes under the most recent aspect of Socially Responsible Investment (SRI). Likewise, Dutta, Jana, and Das (2020) highlighted that these investments received much attention of the investors due to their investment opportunities, as well as the growing perception of the significance of sustainability in terms of the positive impacts to the society. More specifically, investors are in a constant effort to form portfolios that include specifically those companies that promote a positive impact in the society, which is consistent with the Sustainable Development Goals (SDGs). Lagerkvist, Edenbrandt, Tibbelin and Wahlstedt (2020) also claimed that in the recent years, there is a growing importance in promoting the moral aspect, as well as to act in a responsible way of doing business. Furthermore, as highlighted by Yesuf and Aassouli (2020), sustainable or responsible investment is critical, in which the good and positive impacts are considered, along with the risk return trade-off. Sustainable or socially responsible investment pertains to investment that endorses the overall social, financial, and environmental benefits. In this regard, De la Torre, Galeana, and Aguilasocho (2016) mentioned that sustainable investment, that is widely known as socially responsible investment (as their own words) is primarily the "true activity that comes from religious practices such as the ones followed by Muslim, Jewish and Puritan groups, who apply religious and ethical codes for doing business and investing." Furthermore, Chatzitheodorou, Skouloudisb, Evangelinosb and Nikolaou (2019) also highlighted that sustainable investment is defined in many alternative ways, 
so as to primarily distinguish the investment strategies and investment styles by the fund managers. Referring to the importance of Socially Responsible Investment (SRI), Berry and Junkus (2013) wrote in their own words that "it is surprising that there is no consensus of what the term SRI means to an investor". Also, they highlighted different names have been used in the literature, which promote environmental, social and governance factors, including social, sustainable investment, green investment, impact investment, and moral investment. These different names have been undertaken just to differentiate the investment strategy by the investment managers. Investment that is compliant with the Shariah laws is also considered on same principles, which pertain to the Sustainable Development Goals that promote and prefer the social benefits in its objectives. There is also a screening criterion, as highlighted by Chowdhury and Masih (2015) that Shariah compliance tends to share similar objectives and characteristics that are consistent with the definitions of sustainable, social, moral, green, or impact investment. There is also common understanding among the different definitions and screening criteria of these investments that the objective is not toto harm the society, and to also endorse the social, moral, and positive impacts. Following the literaturebased discussion, as well as to promote the culture that may facilitate to attain the targets of Sustainable Development Goals, Azmi et al. (2019) argues that Islamic investment can be categorized as a subset of Socially Responsible Investments. Therefore, this study considers the Shariahcompliant equity portfolios as sustainable equity portfolios, in order to study the dynamics of price discovery, asset pricing, and portfolio optimization.

Furthermore, the investment that is socially harmful to society at large, as endorsed by ESG factors, is also restricted by the Islamic mode of investment. It is noteworthy that the Islamic mode of investment follows the guidelines that are provided by Shariah. Shariah can be defined as the rules and regulations provided by the five sources of Shariah. These are the Quran, Hadith, Ijma, Qiyas, and Ijtihad. Any guidelines from these five sources are considered to be Shariah compliant. Many researchers have mentioned screening criteria, these include Aloui, Hkiri, Marco, and Yarovaya (2016) and Jaballah, Peillex, and Weill (2018). However, Rizvi, Arshad, and Alam (2015) mentioned that this screening process excludes some companies that are based on debt, particularly from the investment cloud. Moreover, Hussein and Omran (2005) wrote that this will translate into small investable companies with more risk. At another instance, Boubakri, Chen, Guedhami and $\mathrm{Li}(2019)$ stated that the low-risk patterns, due to the screening process, and sustainable equities may have higher liquidity. Hence, their performance and pricing may differ from the other stocks. 
The Financial Times Stock Exchange (FTSE) Quality of Markets Criteria (Asia Pacific) as of September 2020, classified the equity market of Pakistan of being speculative. They suspected that it reflected incomplete information, risky but profitable characteristics. Whereas, the Morgan Stanley Capital Index (MSCI) as of June 17, 2020 declared the Pakistan stock market as an emerging equity market. This was the first time Pakistan stock market was included as an emerging market in May 2017. As per the FTSE ranking, this market was deemed to be more speculative, by having incomplete information, with risky but profitable characteristics. Motivated by Miralles-Quirós et al. (2020) and Narayan et al. (2016), we have thus investigated the Fama-French three factor model, liquidity based three factor asset pricing model, and have also tested the evidence of price discovery in sustainable equity portfolios that are listed in the Pakistan Stock Exchange.

\section{Literature Review}

The portfolio theory by Markowitz (1952) was the seminal contribution in academic literature, and has practical application in the investment world as well. The portfolio theory claims that in the existence of the lowest possible correlation, investors can reduce their total risk by investing in multiple assets. Following the seminal contribution of the portfolio theory, in the field of asset pricing, the revolutionary approach to price equity stocks was developed by Sharpe (1964), which was called the Capital Asset Pricing Model. CAPM was an extension of the portfolio theory, and included risk-free assets in the construction portfolio that was one of the big achievements in the valuation of risky assets. The assumptions of the CAPM were purely based on the portfolio theory. That is to say that here it was assumed that no inflation, tax or transaction cost exist, and the investor can borrow or lend any amount, at risk free rate, and there is no mispricing in the pricing of the equity stocks or markets which were efficient. The idea of market efficiency was based on the theory that was essentially developed by Fama (1970).

During the course of the decade, Mossin (1966) and Linter (1965) also worked on the aspect of equity pricing, with respect to their undiversifiable risk. They also concluded in terms of the same findings, and the latter on asset pricing model was also called the Sharpe-Linter-Mossin CAPM. In addition to this, Ross (1976) proposed the Arbitrage Pricing Theory (APT), which was presented as an extension, and an alternative to the Capital Asset Pricing Model, which contended that there are multiple factors that can affect equity returns. However though, he was unable to find the number of 
factors there actually were to be considered. After the arbitrage pricing theory, many researchers worked to find the missing factors that might have affected the equity returns. Despite the single or multiple factors, Roll (1977) raised logical questions based on the efficiency of the mean-variance portfolios, and also criticized that no single market can be used as a benchmark for the market index, so as to find market risk premium. He also found inconsistent results in relation to the CAPM in his study. Banz (1981) also concluded that the stock sorted that is primarily based on market capitalization worked better than of the explanation of the risk return by CAPM. Motivated by previous findings, under the umbrella of the arbitrage pricing theory, Fama and French $(1992,1993)$ found contradicting results with the CAPM in their seminal work. They also proposed that the model with the market risk premium, and other factors such as the portfolios that have been sorted on market capitalization, and book value of equity, divided by market value of equity, perform better than the CAPM. Javid and Ahmad (2009) found that the multifactor model explains the equity portfolio return in a thorough manner.

Moreover, Hassan (2010) worked on the systematic risks and asset pricing in Pakistan. The finding of this study revealed that the historical beta did not predict the expected returns under the CAPM, but the excess return of the market tends to have a significant positive relationship with the equity portfolio returns, size, B/M, and illiquidity premium. Fama and French (2012) also worked to investigate the size, value, and momentum premium in the international equity in Europe, Japan, Asia Pacific, and North America. They found that except in the case of Japan, the B/M decreases with size, and momentum premium also decreases from the small portfolios to big portfolios. Chen and Bassett (2013) also mentioned that in academia, the Fama-French three-factor model is considered as a quality conscious and standard academic technique for the pricing of individual, as well as for the portfolios. In addition to this, Foye, Mramor, and Pahor (2013) also studied the Fama-French model, and found that the market value of the equity component did not perform well in the emerging markets, as compared to the same in the Eastern European countries. At another instance, Fatima (2016) also studied the Fama-French three factor model in Pakistan, India, and China, for the period spanning from 2000 to 2015. The findings of this study revealed that the market premium and the value premium significantly predict the equity portfolio returns. It also revealed that the size premium factor performed well in terms of the size sorted small stocks, as compared to the large stocks. She also concluded that the explanatory power of the Fama-French three factor model was found to be greater than CAPM in Pakistan, India and China, and mentioned that the multifactor asset 
pricing models can facilitate investors in getting well diversified, efficient portfolio optimization. Rehnby (2016) also studied the Swedish stock market, in order to empirically test the CAPM, Fama-French three factor, and the Carhart four factor. The study concluded that the Fama-French three factor model has a better explanatory power than the CAPM, whereas the Carhart four factor model provides little superiority as compared to the Fama-French three factor model. He also indicated that all the models were reported to show a low level of explanatory power in volatile market conditions.

At another instance, Chughtai (2016) also worked in the realm of asset pricing and stylized the facts for a multi-factor world in Pakistan specifically for the period pertaining to 2002 to 2012, with the 189 companies that were listed on the Karachi Stock Exchange. The results of the study revealed that the explanatory power of Fama-French three factor model was good, and significant for Pakistani equity, as compared to the Carhart four factor and Fama-French five factor models. Moreover, Tauscher and Wallmeier (2016) also wrote that largely, the empirical evidence of FamaFrench three factor model in the United States markets, with market capitalization and book to market value, sorted the factors as an explanation of the expected returns. Evidence of this was confirmed in the markets of Japan, Asian Pacific, and Europe. Kubota and Takehara (2017) also tested the Fama-French five factor model in Japan, for a study period pertaining to 1978-2014. They found that the profitability and investment factors were not statistically significant, and also concluded that the original version of the Fama-French five factor model was not able to capture the risk and return dynamics for the Japanese stock market data. Furthermore, Qasim (2018) also studied the aspect of market premium, size premium, and value premium, of the 80 listed companies listed in the Pakistan Stock Exchange, for the period pertaining to 2006-2015. The study results revealed that the market premium and momentum premium significantly explained the equity returns, whereas the stocks were sorted based on market capitalization, and the book to market ratio did not perform well in the equity market of Pakistan. Zada, Rehman and Khwaja (2018) also worked extensively on the Fama-French five factor model in Pakistan, specifically for the period pertaining to the year 2000-2013, for the size sorted, 120 companies that were listed in the Pakistan Stock Exchange (PSX). It was found that the Fama-French five factor model significantly predicted the equity portfolio returns. Safiullah and Shamsuddin (2019) also studied the asset pricing factors in the Islamic equity returns in 42 Dow Jones Islamic and non-Islamic equity indices, for the time period spanning from January 1996 to December 2017, using the Fama-French five factor model. They 
found that the overall Islamic equity portfolios performed well than the nonIslamic equity portfolios, in the Fama-French five factor model. They also stated that the findings tend to be robust after using the liquidity based Fama-French five factor model. More importantly, they also mentioned that the GRS test suggested that these asset pricing models may not be adequate for the appropriate pricing of the equity portfolios of Islamic, and nonIslamic equity portfolios.

At another instance, Saeed (2020) studied the liquidity risks and the asset pricing in Pakistan, including Japan, India, China, and Thailand, for the study period pertaining to 2005-2015. She found that liquidity was critical, yet the least prominent risk factor for asset pricing, in the case of Asian markets. Azimli (2020) also worked on pricing the common stocks in an emerging capital market. This was undertaken by using the cash-based profitability factor, in order to test the Fama-French five factor, and the three factor models, against the eight different market anomalies in Borsa, Istanbul. He found that the aspect of systematic risk and value premium were significantly predicted in Borsa, Istanbul, whereas the investment and profitability factor did not add value. In the same context, Gavious and Kedar-Levy (2013) mentioned in their article that the research undertaken on the price discovery, with the asset pricing is a rare occurrence in the asset pricing domain. Moreover, Narayan et al. (2016) implicitly studied the relationship of price discovery and asset pricing for 21 time series in the Islamic equity portfolios. A sample of 188 stocks were part of the Dow Jones Islamic Asia-Pacific Index, and another set was from 16 Asia Pacific countries. Their hypothesis was that the price discovery is statistically and economically useful for asset pricing. Narayan et al. (2016) discovered and tested the economic significance of price discovery, using the portfolio optimization, and found that all those portfolios were profitable where the price discovery and asset pricing were linked.

\section{Data Collection and Research Methodology}

In this study, all the listed companies (217) at the PSX-KMI All Share Index have been used as the population for sustainable equity investment. In addition to this, this study has also used equities that remained a part of the index consistently, for the study period pertaining to 2015 till 2020. After the preliminary data screening that has given below, 78 companies were sampled from the population. The sample period, and the shortlisted companies are supported by a study published in The Journal of Finance by Chakravarty Gulen, and Mayhew (2004), which focuses on the price discovery measures for five years, in 60 firms. 
Moreover, this study uses secondary monthly data of the shortlisted equities. Also, the accounting data based on different variables has also been manually calculated from the annual reports and financial statements. Some other variables have also been calculated from the Pakistan Stock Exchange, Business Recorder, and State Bank of Pakistan. In this study, the Fama and French three factor, and the liquidity based three factor models have been tested. Following the methodology of Fama and French $(1992,1993)$, this study has used the $2 \times 2 \times 2$ sorting, in order to create the portfolios. The equations of such have been given below:

Fama and French three factor model:

$$
r=R f+\beta_{1}(r m-r f)+\beta_{2} S M B+\beta_{3} H M L+e
$$

Size sorted illiquidity-based three factor model:

$$
r=R f+\beta_{1}(r m-r f)+\beta_{2} S M B+\beta_{3} I L L I Q+e
$$

Fama-French five factor model:

$$
r=\underset{e .}{R f}+\beta_{1}(r m-r f)+\beta_{2} S M B+\beta_{3} H M L+\beta_{4} R M W+\beta_{5} C M A+
$$

In equation (1), $r m-r f$ is the market risk premium, $\mathrm{SMB}$ is the size premium i.e., small minus big stocks, and HML is the value premium i.e., high minus low B/M stocks. The size sorted illiquidity-based three factor model is the modified version of Fama-French three factor model in which ILLIQ is the illiquidity premium measured as low liquid stocks minus high liquid stocks. Likewise, in equation 3 Fama-French five factor model include RMW i.e., robust minus weak and CMA i.e., conservative minus aggressive investment stocks alongwith market risk premium, size premium, and value premium.

Whereas, in order to test the existence of the price discovery model, following Amairi, Zantour and Saadi (2021), this study has resorted to the use of the VR Test (Chow \& Denning, 1993), using the Wild bootstrap procedure as recommended by $\operatorname{Kim}(2006)$.

\section{Results and Findings}

The descriptive statistics of the Fama-French three factor model have been given in Table 1(a), where size variable is the only factor that shows a positive mean return, with the lowest standard deviation, as 
compared to the market risk premium and the value premium. Whereas, in Table 1(b), the description of 25 portfolios have been given. The portfolios were created based on the size and the B/M Ratio where mean return was found negative in all the portfolios. Whereas, S2H1 had the highest standard deviation. Moreover, $\mathrm{S} 2 \mathrm{H} 4$ and $\mathrm{S} 1 \mathrm{H} 3$ had the largest maximum average return, whereas $\mathrm{S} 5 \mathrm{H} 3$, and $\mathrm{S} 2 \mathrm{H} 3$ had the lowest average maximum return.

Table 1(a) Descriptive Statistics of Market, Size and Value Premium

\begin{tabular}{lccccc}
\hline Variable & Obs & Mean & Std. Dev. & Min & Max \\
\hline Market Premium & 61 & -0.081 & 0.084 & -0.350 & 0.113 \\
Size Premium & 60 & 0.003 & 0.039 & -0.138 & 0.106 \\
Value Premium & 60 & -0.021 & 0.041 & -0.119 & 0.077 \\
\hline
\end{tabular}

Table 1(b) Descriptive Statistics of Portfolios

\begin{tabular}{lccccc}
\hline Variable & Obs & Mean & Std. Dev. & Min & Max \\
\hline S1H1 & 17 & -0.054 & 0.157 & -0.288 & 0.297 \\
S1H2 & 51 & -0.066 & 0.100 & -0.349 & 0.201 \\
S1H3 & 57 & -0.069 & 0.133 & -0.299 & 0.568 \\
S1H4 & 60 & -0.073 & 0.087 & -0.241 & 0.214 \\
S1H5 & 60 & -0.091 & 0.077 & -0.299 & 0.089 \\
S2H1 & 60 & -0.072 & 0.173 & -0.467 & 0.611 \\
S2H2 & 58 & -0.073 & 0.139 & -0.424 & 0.328 \\
S2H3 & 60 & -0.087 & 0.082 & -0.260 & 0.081 \\
S2H4 & 55 & -0.078 & 0.157 & -0.393 & 0.658 \\
S2H5 & 60 & -0.081 & 0.086 & -0.287 & 0.140 \\
S3H1 & 60 & -0.065 & 0.096 & -0.304 & 0.186 \\
S3H2 & 60 & -0.072 & 0.105 & -0.530 & 0.121 \\
S3H3 & 57 & -0.073 & 0.124 & -0.415 & 0.323 \\
S3H4 & 58 & -0.088 & 0.120 & -0.480 & 0.164 \\
S3H5 & 57 & -0.106 & 0.120 & -0.442 & 0.142 \\
S4H1 & 60 & -0.074 & 0.102 & -0.362 & 0.186 \\
S4H2 & 57 & -0.063 & 0.098 & -0.266 & 0.224 \\
S4H3 & 59 & -0.073 & 0.134 & -0.376 & 0.226 \\
S4H4 & 56 & -0.096 & 0.104 & -0.292 & 0.235 \\
S4H5 & 55 & -0.105 & 0.121 & -0.446 & 0.194 \\
S5H1 & 60 & -0.070 & 0.087 & -0.339 & 0.204 \\
\hline
\end{tabular}




\begin{tabular}{lccccc}
\hline Variable & Obs & Mean & Std. Dev. & Min & Max \\
\hline S5H2 & 59 & -0.067 & 0.070 & -0.232 & 0.094 \\
S5H3 & 60 & -0.070 & 0.099 & -0.441 & 0.081 \\
S5H4 & 60 & -0.083 & 0.095 & -0.377 & 0.123 \\
S5H5 & 28 & -0.106 & 0.148 & -0.663 & 0.155 \\
\hline
\end{tabular}

Table 2: Correlation Matrix

\begin{tabular}{lrrr}
\hline Variables & $\mathbf{( 1 )}$ & $\mathbf{( 2 )}$ & $\mathbf{( 3 )}$ \\
\hline (1) Market Premium & 1.000 & & \\
& & & \\
(2) Size Premium & $-0.469^{* * *}$ & 1.000 & \\
& $(0.000)$ & & \\
(3) Value Premium & 0.137 & $-0.370^{* * *}$ & 1.000 \\
& $(0.296)$ & $(0.004)$ & \\
\hline
\end{tabular}

${ }^{* * *} p<0.01,{ }^{* *} p<0.05, * p<0.1$

The correlation between the market premium, size premium and the value premium along with level of significance is given in Table 2 . The lowest correlation was found between the size premium and the market premium, whereas a positive highest correlation was found to be 0.137 , between the value premium and the market premium.

Following the Fama-French (1993) approach, 25 portfolios were created where the market premium, size and the value premium were regressed against those 25 portfolios as the dependent variables. In this regard, given below are the output results of the regressions (few), where the market premium, size premium, and value premium were found significant for $\mathrm{S} 1 \mathrm{H} 5$ and $\mathrm{S} 2 \mathrm{H} 5$ sustainable equity portfolios. In addition to this, market premium, size premium, and liquidity premium were found to be significant for the pricing equity portfolios in Pakistan. The explanatory power of S1H5 was higher than the other models as well. However, all the other reported portfolios performed well, as a plausible explanation of the equity returns. Furthermore, the p-value of all the factors were less than the level of significance alpha 0.05 , which shows their significant explanation. 
Table 3: Regression Results (Few) from Three Factor Models

\begin{tabular}{lccc}
\hline Dependent Variable & Factors & Coefficients & p-value \\
\hline S1H5 & RM-RF & 0.8983 & 0.000 \\
& SMB & 0.7490 & 0.000 \\
& HML & 0.6122 & 0.000 \\
cons & -.01206 & 0.153 \\
& $\mathrm{R}^{2}$ & 0.7361 & \\
& Adj. $\mathrm{R}^{2}$ & 0.7220 & \\
& RM-RF & .8931 & 0.000 \\
S2H5 & SMB & .7581 & 0.001 \\
& HML & .8385 & 0.000 \\
& cons & .00238 & 0.823 \\
& R & 0.6536 & \\
& Adj. R & 0.6350 & \\
S1H1 & RM-RF & 0.7575 & 0.000 \\
& SMB & 0.4930 & 0.034 \\
& ILLIQ & 0.6191 & 0.001 \\
& Cons & -.0275 & 0.019 \\
& $\mathrm{R}^{2}$ & 0.5848 & \\
& Adj. R & 0.5625 & \\
\hline
\end{tabular}

While, for companies that are less liquid, the supposed factor liquidity significantly explains the portfolio returns. This shows that the liquidity is an important factor variable to price sustainable stocks in Pakistan.

Moreover, the explanatory power is 58.48 for the size sorted liquidity based three factor model. The coefficient values less than 0.05 for all factor variables i.e., market risk premium, size premium and illiquidity premium shows that all the factors are explaining the portfolio returns.

Table 4: Descriptive Statistics of Size Sorted Liquidity Based Three Factor Model.

\begin{tabular}{lccccc}
\hline Variable & Obs & Mean & Std. Dev. & Min & Max \\
\hline Market Premium & 61 & -0.081 & 0.084 & -0.350 & 0.113 \\
Size Premium & 60 & 0.003 & 0.039 & -0.138 & 0.106 \\
Illiquidity Premium & 60 & 0.004 & 0.041 & -0.082 & 0.096 \\
\hline
\end{tabular}


Table 4 shows the descriptive statistics for the size sorted liquidity based three factor model. It can be observed that the average return for all the factors was found positive, except for market premium and it was highest for illiquidity premium. This essentially shows that liquidity is an important aspect for the pricing of sustainable equity portfolios. However, after the aspect of market premium came into focus, the maximum monthly returns were $9.5 \%$ for the illiquidity factor.

Table 5: Descriptive Statistics of Fama-French Five Factor

\begin{tabular}{lccccccccc}
\hline Variables & Obs & Mean & Std. Dev. & Min & Max & p1 & p99 & Skew. & Kurt. \\
\hline RM RF & 48 & -.041 & 5.644 & -10.82 & 12.874 & -10.82 & 12.874 & .077 & 2.391 \\
SMB & 48 & .708 & 5.576 & -12.039 & 12.286 & -12.039 & 12.286 & -.169 & 2.77 \\
HML & 48 & .85 & 6.173 & -13.357 & 20.17 & -13.357 & 20.17 & .147 & 4.13 \\
RMW & 48 & 1.219 & 5.577 & -12.835 & 13.002 & -12.835 & 13.002 & -.339 & 3.56 \\
CMA & 48 & -1.275 & 5.647 & -13.844 & 11.255 & -13.844 & 11.255 & -.083 & 2.837 \\
\hline
\end{tabular}

Table 5 shows the descriptive statistics for the factors from the Fama-French five factor model. It can be seen that the mean returns for SMB, HML and RMW were positive, except for that in the market premium and CMA. Whereas the maximum returns were 20.17 for HML factor, with the highest standard deviation of 6.173 amongst the other factors.

Table 6: Matrix of Correlations

\begin{tabular}{lrrrrr}
\hline Variables & $\mathbf{( 1 )}$ & $\mathbf{( 2 )}$ & $\mathbf{( 3 )}$ & $\mathbf{( 4 )}$ & (5) \\
\hline (1) RM_RF & 1.000 & & & & \\
& & & & & \\
(2) SMB & -0.221 & 1.000 & & & \\
& $(0.132)$ & & & & \\
(3) HML & -0.220 & $0.498^{* * *}$ & 1.000 & & \\
& $(0.134)$ & $(0.000)$ & & & \\
(4) RMW & 0.085 & $-0.404^{* * *}$ & $-0.404^{* * *}$ & 1.000 & \\
& $(0.565)$ & $(0.004)$ & $(0.004)$ & & \\
(5) CMA & -0.094 & 0.186 & 0.126 & $-0.300^{* *}$ & 1.000 \\
& $(0.524)$ & $(0.206)$ & $(0.394)$ & $(0.038)$ & \\
\hline
\end{tabular}

${ }^{* * *} p<0.01,{ }^{* *} p<0.05,{ }^{*} p<0.1$

Table 6 reports the correlation between the Fama-French five factors along with level of significance. It can be seen that the highest correlation was 0.498 between HML and SMB. Whereas, for SMB and RMRF, HML and RM-RF, CMA and RM-RF, RMW and SMB, RMW and HML, CMA and RMW was found to be negative. 
Fama-French Five Factor Regression Results

Table 7(a): Big Stocks with Low and High B/M Ratio Stocks

\begin{tabular}{lccc}
\hline Dependent Variable & Factors & Coefficients & p-value \\
\hline Big Low B/M & RM-RF & .9736 & 0.000 \\
& SMB & .0896 & 0.544 \\
HML & -.5502 & 0.000 \\
RMW & -.3453 & 0.019 \\
& CMA & -.4094 & 0.002 \\
cons & 2.1247 & 0.005 \\
R $^{2}$ & .7272 & \\
Big High B/M & Adj. R & .6947 & \\
& RM-RF & .8404 & 0.000 \\
& SMB & .2101 & 0.069 \\
& HML & .0083 & 0.934 \\
& RMW & -.1284 & 0.245 \\
& CMA & .2212 & 0.028 \\
& cons & 1.7122 & 0.004 \\
& R & 0.6748 & \\
\hline
\end{tabular}

According to Table $7(\mathrm{a}-\mathrm{c})$, for big sized stocks SMB was insignificant in terms of the presence of the BL portfolio; SMB, HML and RMW for the BH portfolio; SMB, HML, and CMA for the BR portfolio; SMB and HML for the BW portfolio; SMB, HML, and RMW for the BC portfolios; and SMB for the BA portfolios. Whereas according to Table 7(d), for the smaller sized equity portfolios, RMW for the SL portfolio; as per Table 7(e) HML and CMA for the SR portfolio; HML for the SW portfolio; and as per Table 7(f) HML for the SA portfolios were insignificant in nature. Following these results, it was found that all the other factors were explained well for their respective portfolios. However, all five factors from the Fama-French five factor regression, for small conservative and small with high $\mathrm{B} / \mathrm{M}$, were significant. 
Table 7(b): Big Stocks with Robust and Weak Profitability

\begin{tabular}{lccc}
\hline Dependent Variable & Factors & Coefficients & p-value \\
\hline Big Robust & RM-RF & 1.0930 & 0.000 \\
& SMB & -.0804 & 0.322 \\
HML & .0541 & 0.458 \\
RMW & .3390 & 0.000 \\
CMA & -1.132 & 0.063 \\
cons & 1.0039 & 0.015 \\
R $^{2}$ & .8898 & \\
Adj. R & .8767 & \\
& RM-RF & .9435 & 0.000 \\
& SMB & -.0331 & 0.765 \\
& HML & -.0907 & 0.365 \\
RMW & -.4934 & 0.000 \\
& CMA & .2159 & 0.028 \\
& cons & .5859 & 0.287 \\
& $\mathrm{R}^{2}$ & 0.7683 & \\
\hline Adj. R & 0.7408 & \\
\hline
\end{tabular}

Table 7(c): Big Stocks with Conservative and Aggressive Returns

\begin{tabular}{lccc}
\hline Dependent Variable & Factors & Coefficients & p-value \\
\hline Big Conservative & RM-RF & 1.1995 & 0.000 \\
& SMB & .0436 & 0.721 \\
HML & -.0346 & 0.753 \\
RMW & -.1783 & 0.136 \\
CMA & .4048 & 0.000 \\
cons & 1.1265 & 0.067 \\
R 2 & 0.7894 & \\
Big Aggressive & Adj. R 2 & 0.7643 & \\
& RM-RF & 1.0578 & 0.000 \\
& SMB & -.2008 & 0.138 \\
& HML & -.3983 & 0.002 \\
RMW & -.2891 & 0.030 \\
& CMA & -.5521 & 0.000 \\
cons & 1.9526 & 0.005 \\
R 2 & 0.8040 & \\
\hline
\end{tabular}


Table 7(d): Small Stocks with Low and High B/M Stocks

\begin{tabular}{lccc}
\hline Dependent Variable & Factors & Coefficients & p-value \\
\hline Small Low B/M & RM-RF & .9604 & 0.000 \\
& SMB & 1.0507 & 0.000 \\
HML & -.9936 & 0.000 \\
RMW & -.1458 & 0.172 \\
& CMA & .1940 & 0.0440 \\
cons & 1.1555 & 0.037 \\
R $^{2}$ & 0.8644 & \\
Small High B/M & Adj. R & 0.8482 & \\
& RM-RF & 1.0936 & 0.000 \\
& SMB & .9302 & 0.000 \\
& HML & .4476 & 0.001 \\
& RMW & -.3628 & 0.009 \\
& CMA & -.4366 & 0.001 \\
& cons & 1.5680 & 0.024 \\
& R 2 & 0.8283 & \\
\hline
\end{tabular}

Table 7(e): Small Stocks with Robust and Weak Stocks

\begin{tabular}{lccc}
\hline Dependent Variable & Factors & Coefficients & p-value \\
\hline Small Robust & RM-RF & .9198 & 0.000 \\
& SMB & 1.0414 & 0.000 \\
HML & -.1764 & 0.104 \\
RMW & .3625 & 0.003 \\
CMA & .1382 & 0.180 \\
cons & 1.3582 & 0.024 \\
R $^{2}$ & 0.7770 & \\
Adj. R & 0.7504 & \\
Rmall Weak & 1.0693 & 0.000 \\
& RMB & .9941 & 0.000 \\
& HML & -.0314 & 0.764 \\
& RMW & -.8048 & 0.000 \\
& CMA & -.2097 & 0.041 \\
& cons & 1.7764 & 0.003 \\
& R 2 & 0.8753 & \\
\hline
\end{tabular}


Table 7(f): Small Stocks with Conservative and Aggressive Returns

\begin{tabular}{lccc}
\hline Dependent Variable & Factors & Coefficients & p-value \\
\hline Small Conservative & RM-RF & .9277 & 0.000 \\
& SMB & .8629 & 0.000 \\
& HML & -.3479 & 0.004 \\
& RMW & -.3894 & 0.003 \\
& CMA & .2898 & 0.011 \\
& cons & 1.6330 & 0.012 \\
Small Aggressive & R $^{2}$ & 0.7843 & \\
& Adj. R & 0.7586 & \\
& RM-RF & 1.0693 & 0.000 \\
& SMB & 1.1075 & 0.000 \\
& HML & .01578 & 0.900 \\
& RMW & -.2787 & 0.044 \\
& CMA & -.7530 & 0.000 \\
& cons & .8070 & 0.246 \\
& $\mathrm{R}^{2}$ & 0.8150 & \\
\hline Adj. R & 0.7930 & \\
\hline
\end{tabular}

Table 8: Adjusted $\mathbf{R}^{2}$ of Regressions Comparison

\begin{tabular}{lcc}
\hline Portfolios & Big & Small \\
\hline Low B/M & 0.6947 & 0.8482 \\
High B/M & 0.6361 & 0.8079 \\
Robust & 0.8767 & 0.7504 \\
Weak & 0.7408 & 0.8604 \\
Conservative & 0.7643 & 0.7586 \\
Aggressive & 0.7807 & 0.7930 \\
\hline
\end{tabular}

Table 8 shows that the explanatory power from the regression for Small Low B/M, Small High B/M, Small weak stocks, and Small aggressive stocks was larger. Whereas, for big robust stocks, and big conservative stocks it was greater. This essentially gave proof of the explanatory power of these models.

Given below Table 9 shows the results of the null hypothesis of price discovery, using the variance ratio test that resorted to the wild bootstrap methodology. As theorized by O'Hara (2003) and Narayan et al. (2016), there exist the evidence of price discovery in the portfolio classes that was created based on the variable of size. 
Table 9: Evidence of Price Discovery

\begin{tabular}{lcc}
\hline Portfolios & Probability & Null Hypothesis \\
\hline BA & 0.0810 & Accept \\
BC & 0.0110 & Reject \\
BH & 0.0100 & Reject \\
BL & 0.1660 & Accept \\
BR & 0.0820 & Accept \\
BW & 0.0430 & Reject \\
SA & 0.0620 & Accept \\
SC & 0.0110 & Reject \\
SH & 0.0480 & Reject \\
SL & 0.0300 & Reject \\
SR & 0.0320 & Reject \\
SW & 0.0220 & Reject \\
\hline
\end{tabular}

It is noteworthy that the null hypotheses for BA, BL, BR, and SA were accepted. Whereas, the evidence of price discovery was found in the big conservative, big with high $\mathrm{B} / \mathrm{M}$, big weak, small conservative, small high $\mathrm{B} / \mathrm{M}$, small low B/M, small robust, and small weak portfolios. This shows that all the small stocks were performing well. These portfolios can further be used for portfolio optimization and profit maximization, in order to show the economic significance of price discovery-based equity portfolios.

Table 10: Descriptive Statistics for Price Discovery Portfolios

\begin{tabular}{lccccc}
\hline Variables & Obs & Mean & Std. Dev. & Min & Max \\
\hline BL & 48 & 1.7812 & 8.3989 & -14.0390 & 39.6210 \\
BH & 48 & 1.3952 & 5.9082 & -8.1484 & 14.7700 \\
SL & 48 & 0.5900 & 8.8155 & -17.9079 & 24.8262 \\
SH & 48 & 2.6765 & 9.8121 & -10.4148 & 35.3117 \\
BW & 48 & -0.4302 & 6.8447 & -14.8917 & 16.6622 \\
BR & 48 & 1.5300 & 7.2378 & -14.2029 & 21.2468 \\
SW & 48 & 1.6955 & 9.7962 & -14.3875 & 29.2056 \\
SR & 48 & 2.1739 & 7.4622 & -11.2500 & 19.1385 \\
BC & 48 & 0.3454 & 7.9124 & -15.6278 & 23.9146 \\
BA & 48 & 1.7797 & 8.9797 & -14.0847 & 39.8396 \\
SC & 48 & 1.0657 & 8.0965 & -11.9509 & 18.3439 \\
SA & 48 & 2.1806 & 9.6729 & -14.1192 & 25.0082 \\
\hline
\end{tabular}

Table 10 shows the descriptive statistics of the portfolios that were used to test the existence of price discovery. The average mean returns for the big weak portfolios was negative in nature. Whereas average return was highest for $\mathrm{SH}$ portfolio. 


\section{Discussion and Conclusions}

In this study, we have tested the Fama-French three factor model, size sorted liquidity based three factor model, and the Fama-French five factor model in order to extract the pricing of sustainable equity portfolios in Pakistan. This study has also tested the evidence of price discovery on the portfolios that were constructed from the asset pricing models. In this regard, the overall results suggests that the Fama-French three factor, proposed size sorted illiquidity based three factor model, and the FamaFrench five factor model significantly explained the portfolio returns of sustainable equity portfolios. The descriptive statistics of Fama-French three factor model have been given in Table 1(a), which shows that size is the only factor that displays positive mean returns with the lowest standard deviation, as compared to the market risk premium and the value premium. In Table 1(b), the descriptive statistics of 25 portfolios have been given. The portfolios were created based on the size and the value premium where mean return was found negative in all the portfolios. Whereas, $\mathrm{S} 2 \mathrm{H} 1$ had the highest standard deviation. Moreover, $\mathrm{S} 2 \mathrm{H} 4$ and $\mathrm{S} 1 \mathrm{H} 3$ had the largest maximum average return, whereas $\mathrm{S} 5 \mathrm{H} 3$ and $\mathrm{S} 2 \mathrm{H} 3$ had the lowest average maximum return. The correlation between the market premium, size premium and value premium has been given with significance level. In this regard, the lowest correlation was found between SMB and the market premium, whereas the positive highest correlation was 0.1372 between HML and the market risk premium. Following in relation to the Fama-French (1993) model, 25 portfolios were created, where the market premium, size and value premium regressed against those 25 portfolios.

In this context, the output results of regressions (few) have been given in Table 7(a-f), along with the market premium, size premium, and value premium which were found significant for the $\mathrm{S} 1 \mathrm{H} 5$ and $\mathrm{S} 2 \mathrm{H} 5$ for sustainable equity portfolios. In addition to this, the market premium, size premium, and liquidity premium were also found to be significant for the pricing equity portfolios in Pakistan. Moreover, the explanatory power of S1H5 was higher than the other models. However, all the other reported portfolios performed well, which served as an explanation of equity return. The p-value of all the factors were less than the level of significance alpha 0.05 which shows their significant explanation for the pricing of sustainable equity portfolios. While, for less liquid stocks, the supposed 
liquidity factor significantly explains the portfolio returns. This shows that the liquidity happens to be an important factor variable to price sustainable stocks in Pakistan. Moreover, the explanatory power is 58.48 for the size sorted liquidity based three factor model. It can also be observed that the coefficient values less than 0.05 for all factor variables i.e., market risk premium, size premium and illiquidity premium show that all the factors are explaining the portfolio returns.

Table 4 shows the descriptive statistics for the size sorted liquidity based three factor model. It can be observed that the average return for all the factors was found positive, except for market premium and it was highest for illiquidity premium. Which shows that the factor of liquidity is the most important aspect for the pricing of sustainable equity portfolios. However, after the analysis of the market premium, the maximum monthly returns were $9.5 \%$ for the illiquidity factor. In this regard, Table 5 shows the descriptive statistics for the factors from Fama-French five factor model. The mean returns for the SMB, HML and RMW were positive, except for the market premium and CMA. Whereas the maximum returns were 20.17 for the HML factor, with the highest standard deviation of 6.173 amongst the other factors. Furthermore, Table 6 reports the correlation between the factors as well. The highest correlation was 0.498 between HML and SMB. Whereas, for SMB and RM-RF, HML and RM-RF, CMA and RM-RF, RMW and SMB, RMW and HML, CMA and RMW was found to be negative.

According to Table 7(a-f), for the big size stocks, SMB was insignificant for the BL portfolio; SMB, HML and RMW for the $\mathrm{BH}$ portfolio; $\mathrm{SMB}, \mathrm{HML}$, and $\mathrm{CMA}$ for the BR portfolio; $\mathrm{SMB}$ and HML for the BW portfolio; SMB, HML, and RMW for the BC portfolios; and SMB for the BA portfolios. Whereas, for the small sized equity portfolios, RMW for the SL portfolio; HML and CMA for the SR portfolio; HML for the SW portfolio; and HML for the SA portfolios were insignificant in nature. In addition to this, following the results, it was found that all the other factors explained well for their respective portfolios. However, all the five factors from the Fama-French five factor regression for the small conservative, and small with the high $\mathrm{B} / \mathrm{M}$ were significant. Moreover, Table 8 shows that the explanatory power from the regression for Small Low B/M, Small High B/M, Small weak stocks, and Small aggressive stocks was larger. Whereas, 
for the big robust stocks, big conservative stocks, the same was greater. This essentially shows the explanatory power of these models. Moving on further, Table 9 shows the results of the null hypothesis of price discovery, using the variance ratio test, using the wild bootstrap methodology.

As theorized by O'Hara (2003) and Narayan et al. (2016), there exists the evidence of price discovery in the portfolio classes, which was created based on market capitalization. In addition to this, the null hypotheses for BA, BL, BR, and SA were also accepted. Whereas the evidence of the price discovery was found in the big conservative, big with higher $\mathrm{B} / \mathrm{M}$, big weaker, small conservative, small higher $\mathrm{B} / \mathrm{M}$, small lower $\mathrm{B} / \mathrm{M}$, small robust, and small weak portfolios. Which shows that all the small stocks are performing well. These portfolios can further be used for portfolio optimization and profit maximization, in order to show the economic significance of the price discovery-based equity portfolios. In this regard, Table 10 shows the descriptive statistics of the portfolios that were used to test the existence of price discovery. The average mean returns for the big, weak portfolios were negative.

It is noteworthy that in Pakistan, these sustainable equity stocks were less liquid, primarily due to their unavailability of an active trading platform. So, after the inception of the KMI all share index as their active trading platform, the liquidity was proved to be significant in its proposed size sorted illiquidity based three-factor model. Thus, based on the findings of this study it is concluded that liquidity is an important factor while pricing the portfolio's return. Therefore, investors should divert their focus on the illiquidity factor, along with the size and value premium while making critical investment decisions.

\section{Implications, Limitations, and Future Research Directions}

The findings of the study are important for policy, practice, and future research in several ways. First, this study is a timely contribution to the recent literature of asset pricing and price discovery for sustainable equity portfolios that may inculcate appealing implications from emerging markets. In addition, this study is possibly a contextual candidate in synthesizing asset pricing and price discovery research to describe the diversity in the explanation of return dynamics. More importantly, the findings of this research may become a possible reference study for assets 
related to Sustainable Development Goals. Likewise, this study may also be considered important for practitioners to understand the risk-return dynamics in sustainable stocks of emerging markets. Fund managers may use the findings of this study to construct an optimal portfolio. Furthermore, this study is the possible cause to minimize knowledge void and provides a comprehensive analysis on the dynamics of price discovery and asset pricing, and portfolio profit maximization. The findings of this study may not be generalizable due to the small sample and few years of data. This is the main limitation of this study. Future research can further be explored using a large number of securities with a greater period. 


\section{References}

Amairi, H., Zantour, A., \& Saadi, S. (2021). Information dissemination and price discovery. Finance Research Letters, 38, 101482. doi.org/10.1016/j.frl.2020.101482

Azimli, A. (2020). Pricing the common stocks in an emerging capital market: Comparison of the factor models. Borsa Istanbul Review. https://doi.org/10.1016/j.bir.2020.05.002

Azmi, W., Ng, A., Dewandaru, G., \& Nagayev, R. (2019). Doing well while doing good: The case of Islamic and sustainability equity investing. Borsa Istanbul Review, 19(3), 207-218. https://doi.org/10. 1016/j.bir.2019.02.002

Asad, H., \& Cheema, F. K. (2017). An empirical assessment of the q-factor model: evidence from the Karachi Stock Exchange. The Lahore Journal of Economics, 22(2), 117-138

Akbar, M., \& Ali, S. (2010). A test of the validity of the CAPM in Pakistani equity market. Business E Economic Review, 2(1), 23-28.

Aloui, C., Hkiri, B., Lau, C. K. M., \& Yarovaya, L. (2016). Investors' sentiment and US Islamic and conventional indexes nexus: A timefrequency analysis. Finance Research Letters, 19, 54-59. https://doi.org/10.1016/j.frl.2016.06.002

Berggrun, L., Cardona, E., \& Lizarzaburu, E. (2020). Firm profitability and expected stock returns: Evidence from Latin America. Research in International Business and Finance, 51, 101119. https://doi.org/ 10.1016/j.ribaf.2019.101119

Brandt, M. W., \& Kavajecz, K. A. (2004). Price discovery in the US Treasury market: The impact of order flow and liquidity on the yield curve. The Journal of Finance, 59(6), 2623-2654. https://doi.org/10.1111/ j.1540-6261.2004.00711.x

Bera, A. K., Uyar, U., \& Uyar, S. G. K. (2020). Analysis of the five-factor asset pricing model with wavelet multiscaling approach. The Quarterly Review of Economics and Finance, 76, 414-423. https:// doi.org/10.1016/j.qref.2019.09.014 
Berry, T. C., \& Junkus, J. C. (2013). Socially responsible investing: An investor perspective. Journal of Business Ethics, 112(4), 707-720. https://doi.org/10.1007/s10551-012-1567-0

Boubakri, N., Chen, R., Guedhami, O., \& Li, X. (2019). The Stock Liquidity of Banks: A Comparison between Islamic and Conventional Banks in Emerging Economies. Emerging Markets Review, 39, 210-224. https://doi.org/10.1016/j.ememar.2019.03.006

Banz, R. W. (1981). The relationship between return and market value of common stocks. Journal of Financial Economics, 9(1), 3-18. https://doi.org/10.1016/0304-405X(81)90018-0

Chakravarty, S., Gulen, H., \& Mayhew, S. (2004). Informed trading in stock and option markets. The Journal of Finance, 59(3), 1235-1257. https://doi.org/10.1111/j.1540-6261.2004.00661.x

Chughtai, S. (2016). Asset pricing and stylized facts for a multifactor world: a model beyond conventional anomalies. (Doctoral dissertation). https://cust.edu.pk/asset-pricing-and-stylized-facts-for-a-multifactor-world-a-model-beyond-conventional-anomalies /

Chatzitheodorou, K., Skouloudis, A., Evangelinos, K., \& Nikolaou, I. (2019). Exploring socially responsible investment perspectives: A literature mapping and an investor classification. Sustainable Production and Consumption, 19, 117-129. https://doi.org/10.1016/ j.spc.2019.03.006

Chowdhury, M. A. F., \& Masih, M. (2015). Socially responsible investment and Shariah-compliant investment compared: Can investors benefit from diversification? An ARDL approach. MPRA Paper No. 65828, https://mpra.ub.uni-muenchen.de/65828/

Chai, D., Chiah, M., \& Gharghori, P. (2019). Which model best explains the returns of large Australian stocks? Pacific-Basin Finance Journal, 55, 182-191. https://doi.org/10.1016/j.pacfin.2019.04.002

Carhart, M. M. (1997). On persistence in mutual fund performance. The Journal of Finance, 52(1), 57-82. https:/ / doi.org/10.2307/2329556

Dirkx, P., \& Peter, F. J. (2020). The Fama-French Five-Factor Model plus Momentum: Evidence for the German Market. Schmalenbach 
Business Review, 72(4), 661-684. https://doi.org/10.1007/s41464020-00105-y

Doshi, H., Jacobs, K., Kumar, P., \& Rabinovitch, R. (2019). Leverage and the Cross-Section of Equity Returns. The Journal of Finance, 74(3), 14311471. https://doi.org/10.1111/jofi.12758

Derigs, U., \& Marzban, S. (2008). Review and analysis of current Shariahcompliant equity screening practices. International Journal of Islamic and Middle Eastern Finance and Management, 1(4). https://doi.org/10.1108/17538390810919600

De la Torre, O., Galeana, E., \& Aguilasocho, D. (2016). The use of the sustainable investment against the broad market one. A first test in the Mexican stock market. European Research on Management and Business Economics, 22(3), 117-123. https://doi.org/10.1016/ j.iedee.2015.08.002

Dutta, A., Jana, R. K., \& Das, D. (2020). Do green investments react to oil price shocks? Implications for sustainable development. Journal of Cleaner Production, 266, 121956. https://doi.org/10.1016/ j.jclepro.2020.121956

Easley, D., Hvidkjaer, S., \& O'Hara, M. (2002). Is information risk a determinant of asset returns? The Journal of Finance, 57(5), 21852221. https://doi.org/10.1111/1540-6261.00493

Ernst, T. (2019). Stock-Specific price discovery from ETFs. Working paper, Massachusetts Institute of Technology. Available at https://www.mit.edu/ ternst/docs/jmp.pdf

Fatima, N. (2016). Cash to price ratio and stock returns: empirical study in emerging markets (Pakistan, India, China). (Master of Science dissertation). Retrieved from https://thesis.cust.edu.pk/ UploadedFiles/Nudrat\%20Fatima-MMS151056.pdf

Fama, E. F., \& French, K. R. (2018). Choosing factors. Journal of Financial Economics, 128(2), 234-252. https://doi.org/10.1016/j.jfineco.2018. 02.012 
Fama, E. F., \& French, K. R. (2015). A five-factor asset pricing model. Journal of Financial Economics, 116(1), 1-22. https://doi.org/10.1016/ j.jfineco.2014.10.010

Fama, E. F. (1970). Efficient capital markets: A review of theory and empirical work. The Journal of Finance, 25(2), 383-417. https://doi.org/10.1111/j.1540-6261.1970.tb00518.x

Fama, E. F., \& MacBeth, J. D. (1973). Risk, return, and equilibrium: Empirical tests. Journal of Political Economy, 81(3), 607-636. https://www.jstor.org/stable/1831028

Fama, E. F., \& French, K. R. (1992). The cross-section of expected stock returns. The Journal of Finance, 47(2), 427-465. https://doi.org/ $10.2307 / 2329112$

Fama, E. F., \& French, K. R. (1993). Common risk factors in the returns on stocks and bonds. Journal of Financial Economics, 33(1), 3-56. https://doi.org/10.1016/0304-405X(93)90023-5

Fama, E. F., \& French, K. R. (1996). Multifactor explanations of asset pricing anomalies. The Journal of Finance, 51(1), 55-84. https://doi.org/ $10.2307 / 2329302$

Foye, J. (2018). A comprehensive test of the Fama-French five-factor model in emerging markets. Emerging Markets Review, 37, 199-222. https://doi.org/10.1016/j.ememar.2018.09.002

Foye, J., \& Valentinčič, A. (2020). Testing factor models in Indonesia. Emerging Markets Review, 42, 100628. https://doi.org/10.1016/ j.ememar.2019.100628

Gavious, A., \& Kedar-Levy, H. (2013). The speed of stock price discovery. Journal of Financial Intermediation, 22(2), 245-258. https://doi.org/ 10.1016/j.jfi.2012.09.003

Green, R. C., Li, D., \& Schürhoff, N. (2010). Price discovery in illiquid markets: Do financial asset prices rise faster than they fall? The Journal of Finance, 65(5), 1669-1702. https:/ / doi.org/10.1111/j.15406261.2010.01590.x 
Hammami, Y., \& Lindahl, A. (2013). Estimating and testing beta pricing models on industries. Journal of Economics and Business, 69(C), 45-63. https://doi.org/10.1016/j.jeconbus.2013.05.003

Hasan, A. (2010). Systematic risks and asset pricing: an integrated multifactor model for asset pricing in Pakistani equity market. (Doctoral dissertation). https://cust.edu.pk/static/uploads/ 2018/10/Arshad-Hassan.pdf

Hussein, K., \& Omran, M. (2005). Ethical investment revisited: evidence from Dow Jones Islamic indexes. The Journal of Investing, 14(3), 105126. https://doi.org/10.3905/joi.2005.580557

Horváth, D., \& Wang, Y. L. (in press). The examination of Fama-French Model during the Covid-19. Finance Research Letters, 101848. https://doi.org/10.1016/j.frl.2020.101848

Ishtiaq, M., Tufail, M. S., Muneer, S., \& Sarwar, M. B. (2019). Application of Fama-French Five Factor Model in Stock Pricing: Evidence from Emerging Market. Pacific Business Review International, 11(7), 73-95.

Jaballah, J., Peillex, J., \& Weill, L. (2018). Is Being Sharia compliant worth it? Economic Modelling, 72, 353-362. https://doi.org/10.1016/ j.econmod.2018.02.011

Jegadeesh, N., \& Titman, S. (1993). Returns to buying winners and selling losers: Implications for stock market efficiency. The Journal of Finance, 48(1), 65-91. https:/ /doi.org/10.2307/2328882

Kim, J. H. (2006). Wild bootstrapping variance ratio tests. Economics Letters, 92(1), 38-43. https://doi.org/10.1016/j.econlet.2006.01.007

Lettau, M., \& Pelger, M. (2020). Estimating latent asset-pricing factors. Journal of Econometrics. 218(1), 1-31. https://doi.org/ 10.1016/j.jeconom.2019.08.012

Lin, H., Wang, J., \& Wu, C. (2011). Liquidity risk and expected corporate bond returns. Journal of Financial Economics, 99(3), 628-650. https://doi.org/10.1016/j.jfineco.2010.10.004

Markowitz, H. M. (1952). (1952). Portfolio selection. The Journal of Finance, 7(1), 77-91. https://doi.org/10.1111/j.1540-6261.1952.tb01525.x 
Miralles-Quirós, J. L., Miralles-Quirós, M. M., \& Nogueira, J. M. (2020). Sustainable Development Goals and Investment Strategies: The Profitability of Using Five-Factor Fama-French alphas. Sustainability, 12(5), 1842. https://doi.org/10.3390/su12051842

Mosoeu, S., \& Kodongo, O. (in press). The Fama-French five-factor model and emerging market equity returns. The Quarterly Review of Economics and Finance. https://doi.org/10.1016/j.qref.2020.10.023

Mselmi, N., Hamza, T., Lahiani, A., \& Shahbaz, M. (2019). Pricing corporate financial distress: Empirical evidence from the French stock market. Journal of International Money and Finance, 96, 13-27. https://doi.org/10.1016/j.jimonfin.2019.04.008

Mateus, I. B., Mateus, C., \& Todorovic, N. (2019). Review of new trends in the literature on factor models and mutual fund performance. International Review of Financial Analysis, 63 (May 2019), 344-354. https://doi.org/10.1016/j.irfa.2018.12.012

Mossin, J. (1966). Equilibrium in a capital asset market. Econometrica, 34(4), 768-783. https://doi.org/0012-9682(196610)34:4<768:EIACAM> 2.0.CO;2-3

Naqvi, B., Rizvi, S. K. A., Mirza, N., \& Reddy, K. (2018). Religion based investing and illusion of Islamic Alpha and Beta. Pacific-Basin Finance Journal, 52 (December 2018), 82-106. doi.org/10.1016/j.pacfin.2018.02.003

Narayan, P. K., \& Sharma, S. S. (2018). An analysis of time-varying commodity market price discovery. International Review of Financial Analysis, 57, 122-133. https://doi.org/10.1016/j.irfa.2018.03.008

Narayan, P. K., Phan, D. H. B., Thuraisamy, K., \& Westerlund, J. (2016).

Price discovery and asset pricing. Pacific-Basin Finance

Journal, 40(December 2016), 224-235.

doi.org/10.1016/j.pacfin.2016.08.009

O'Hara, M. (2003). Presidential address: Liquidity and price discovery. The Journal of Finance, 58(4), 1335-1354. https://doi.org/10.1111/15406261.00569 
Qasim, M. (2018). Determining stock market return by using multiple factor model during boom and burst in oil Market. (Master of Science dissertation). https://thesis.cust.edu.pk/UploadedFiles/ Muhammad\%20Qasim-MMS153006.pdf

Rizvi, S. A. R., Arshad, S., \& Alam, N. (2015). Crises and contagion in Asia Pacific-Islamic v/s conventional markets. Pacific-Basin Finance Journal, 34 (September 2015), 315-326. https://doi.org/10.1016/j.pacfin.2015.04.002

Raza, H. (2019). Cost of equity dynamics: a comparison across emerging and developed markets. (Doctoral dissertation). https://prr.hec.gov. pk/jspui/handle/123456789/10390

Ross, S. A. (1976). The arbitrage theory of capital asset pricing. Journal of Economic Theory, 13(3). 341-360. https://doi.org/10.1016/00220531(76)90046-6

Shaikh, S. A., Ismail, M. A., Ismail, A. G., Shahimi, S., \& Shafiai, M. H. M. (2019). Cross section of stock returns on Shari'ah-compliant stocks: evidence from Pakistan. International Journal of Islamic and Middle Eastern Finance and Management. https:/ / doi.org/10.1108/IMEFM04-2017-0100

Safiullah, M., \& Shamsuddin, A. (2019). Asset pricing factors in Islamic equity returns. International Review of Finance, 32(1), 523-554. https://doi.org/10.1111/irfi.12290

Sadaqat, M. (2018). Asset pricing anomalies: the role of liquidity, volatility, and investor sentiment - evidence from Pakistan stock exchange (PSX). (Doctoral dissertation). http://prr.hec.gov.pk/jspui/handle/ $123456789 / 11150$

Saeed, S. (2020). Liquidity risks and asset pricing in Asian stock markets. (Doctoral dissertation). https://cust.edu.pk/liquidity-risks-andasset-pricing-in-asian-stock-markets /

Sha, Y., \& Gao, R. (2019). Which is the best: A comparison of asset pricing factor models in Chinese mutual fund industry. Economic Modelling, 83, 8-16. https://doi.org/10.1016/j.econmod.2019.09.016 
Yesuf, A. J., \& Aassouli, D. (2020). Exploring synergies and performance evaluation between Islamic funds and socially responsible investment (SRIs) in light of the Sustainable Development Goals (SDGs). Heliyon, 6(8), e04562. https://doi.org/10.1016/j. heliyon.2020.e04562

Zaremba, A., Karathanasopoulos, A., Maydybura, A., Czapkiewicz, A., \& Bagheri, N. (2020). Dissecting anomalies in Islamic stocks: Integrated or segmented pricing? Pacific-Basin Finance Journal, 62, 101024. https://doi.org/10.1016/j.pacfin.2018.05.006 
